\title{
Peramalan Penerbitan Ijin Mendirikan Bangunan Dengan Simple Moving Average Dan Exponential Smoothing
}

\author{
I Gst. Ngr. Agung Yogha $\mathrm{P}^{1}$, Rukmi Sari Hartati ${ }^{2}$, Komang Oka Saputra ${ }^{3}$ \\ [Submission: 27-03-2019, Accepted: 24-06-2019]
}

\begin{abstract}
Building Construction Permits are permits granted by the Regional Head to building owners to build new, change, expand, reduce or maintain buildings in accordance with administrative requirements and applicable technical requirements. Forecasting is an estimate or estimate of the occurrence of an event or event in the future. Forecasting is an important tool in efficient and effective planning. The process is to estimate what future needs include needs in terms of quantity, quality, time and location needed to fulfill the demand for goods or services. Forecasting is the initial part of a decision making process. Data for Building Construction Permits (IMB) was calculated using the Simple Moving Average and Exponential Smoothing method to determine the value of Mean Error, Mean Absolute Deviation , Mean Square Error, Standard Error, Mean Absolute Percent Error.

Intisari- Ijin Mendirikan Bangunan adalah ijin yang diberikan oleh Kepala Daerah pada pemilik bangunan untuk mendirikan bangunan, mengubah, memperluas, mengurangi atau merawat bangunan sesuai dengan persyaratan administratif dan persyaratan teknis yang berlaku. Peramalan adalah merupakan perkiraan mengenai terjadinya suatu kejadian pada masa depan. Peramalan merupakan sebuah alat bantu yang penting dalam perencanaan yang efesien dan efektif. Prosesnya untuk mengetahui kebutuhan di masa datang antara lain kebutuhan ukuran kuantitas, kualitas, waktu dan lokasi untuk pemenuhan permintaan barang ataupun jasa. Peramalan merupakan bagian awal dari pengambilan suatu keputusan akhir. Data Ijin Mendirikan Bangunan (IMB) di hitung dengan metode Simple Moving Average dan Exponential Smoothing untuk mengetahui nilai dari Mean Error, Mean Absolute Deviation , Mean Square Error , Standar Error, Mean Absolute Percent Error .
\end{abstract}

Kata Kunci- Ijin Mendirikan sini, Single Moving Average, Exponential Smoothing.

\section{PENDAHULUAN}

Pemerintah sebagai subjek yang melayani masyarakat dalam berbagai aspek hal, salah satunya mengenai pengurusan pelayanan perizinan. Pemerintah telah menyediakan wadah untuk pelayanan perijinan melalui program Pelayanan Perizinan Terpadu Satu Pintu (PPTSP) yang di dalam pelaksanaan dari awal pengajuan hingga menjadi izin-izin yang sah di ajukan pada kantor DPMPTSP.

Proses perizinan yang banyak diajukan oleh masyarakat

Staff perijinan A, DPMPTSP Gianyar, Mahasiswa Pasca Sarjana, Jurusan Manajemen Sistem Informasi dan Komputer, Universitas Udayana, Jl. PB Sudirman Denpasar Bali 80232, INDONESIA (tlp: 0361-239599; e-mail: gunkyogha@gmail.com)

${ }^{2,3}$ Dosen Magister Teknik Elektro, Universitas Udayana, Jl. PB Sudirman Denpasar Bali 80232, INDONESIA (tlp: 0361-239599; e-mail: ${ }^{1}$ rshartati@gmail.com , ${ }^{2}$ okasaputra@unud.ac.id) kabupaten Gianyar yaitu Izin Mendirikan Bangunan. Peraturan Daerah kabupaten Gianyar No. 8 tahun 2013 mengenai Izin Mendirikan Bangunan gedung yang selanjutnya disingkat IMB adalah izin yang diberikan oleh pemerintah daerah kepada pemilik untuk membangun baru, mengubah, memperluas, mengurangi atau merawat bangunan gedung sesuai dengan persyaratan administratif dan persyaratan teknis [1].

Ijin mendirikan bangunan adalah ijin yang terbit setelah dilakukan survey lapangan dan melengkapi dokumen administrasi serta memenuhi ketentuan seperti teknis, pertanahan, kesehatan, lingkungan dan perencanaan. [2].

IMB adalah salah satu produk hukum yang berfungsi untuk menata, menertibkan dan menciptakan kenyamanan dalam hal pembangunan bangunan. IMB juga mensahkan suatu bangunan sesuai dengan aturan tata ruang yang berlaku serta perencanaan kontruksi bangunan juga bisa di pertanggungjawabkan [3].

Banyaknya permohonan IMB yang masuk membutuhkan proses analisa peramalan guna mengetahui kebutuhan jumlah pencetakan stok awal plat nomor bangunan yang dimana hal tersebut juga di telah persiapkan dalam anggaran biaya pada DPMPTSP kabupaten Gianyar.

Pada Peraturan Menteri Pekerjaan Umum Dan Perumahan Rakyat No.05/PRT/M/2016 memaparkan bahwa permohonan dilakukan oleh pemilik bangunan kepada pemerintah daerah untuk mendapatkan ijin mendirikan bangunan[4]. Kepemilikan Ijin Mendirikan Bangunan merupakan hal yang wajib dipenuhi ada disetiap kita mendirikan suatu bangunan. IMB merupakan salah satu syarat sah yang harus ada saat terjadi suatu transaksi jual beli suatu bangunan.

Peramalan dapat di bagi dalam kelompok waktu yaitu jangka panjang, menengah dan pendek. Peramalan dengan waktu yang panjang yaitu peramalan dengan kurun waktu 2 tahun atau lebih contohnya seperti penganggaran biaya produksi barang. Peramalan jangka menengah memakan waktu 3 bulan sampai 12 bulan seperti rencana penjualan. Peramalan singkat adalah yang kurang dari 3 bulan seperti perencanaan pembelian material [5].

Moving average (MA) merupakan teknik peramalan Time Series yaitu suatu hitungan yang digunakan pada bidang seperti ilmu ekonomi dan statistika untuk analisa data seperti naik dan turun harga dalam grafik pada beberapa tahun kebelakang dengan waktu singkat, analisa tren harga, dan lainnya.

Metode Simple Moving Average adalah metode peramalan dengan mengambil nilai dari pengamatan serta mendapatkan nilai rata-rata tersebut sebagai ramalan pada tahun kebelakang yang datang. Rata-rata bergerak pada metode ini dikarenakan jika data observasi baru tersedia, maka berpengaruh pada nilai rata-rata baru dihitung dan digunakan sebagai nilai ramalan.

I Gst. Ngr. Agung Yogha P: Peramalan Penerbitan Ijin Mendirikan...

p-ISSN:1693 - 2951; e-ISSN: 2503-2372

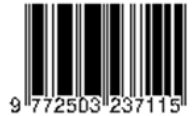


Simple Moving Averange mempunyai terdiri dari faktor penyebab yang berlaku pada masa lalu yang dipakai pada masa dating. Peramalan tidak pernah akan memliki hasil sempurna, faktanya pada jumlahnya selalu berbeda dengan permintaan yang diramalkan, serta pada tingkat ketepatan ramalan akan semakin berkurang dalam kurun waktu yang semakin lama [6].

Metode deret waktu lain seperti Exponential Smoothing Model adalah metode sifat data tidak stabil atau perubahan yang terjadi sangat besar pada model pemulusan. Metode Exponential Smoothing bermanfaat pada peramalan hal-hal yang bersifat fluktuasinya atau tidak teratur. Pemulusan Eksponential merupakan peramalan rata-rata bergerak dengan pembobotan nilai serta mudah diimplementasikan. Metode ini bersumber pada pencatatan data masa lampau yang telah tersimpan. Metode ini menggunakan data berfluktuasi di sekitar nilai rata-rata tetap, tanpa mengikuti pola [7].

Penggabungan metode Simple Moving Average dan Exponential Smoothing bertujuan membandingkan nilai persentase peramalan terdekat dengan data actual pada IMB yang terbit di tahun 2018 ini. Hal hal yang akan dijadikan perbandingan antara kedua metode di atas antara lain mencari nilai Mean Absolute Deviation, Mean Squared Error dan Mean Absolute Error sehingga di dapatkan nilai peramalan yang paling mendekati actual. Pengujiannya akan dimulai dengan penerapan menggunakan Simple Moving Average dengan memakai tahun kebelakang waktu uji 2 tahun hingga 8 tahun kebelakang sebelum tahun 2018. Setelah itu data IMB kembali diuji dengan Exponential Smoothing menggunakan $\alpha$ $=0,10, \alpha=0,50, \alpha=0,70$, dan $\alpha=0,90$ dengan 2 tahun kebelakang tahun pada setiap pengujian alpha.

\section{METODE PENELITIAN}

\subsection{Peramalan}

Peramalan merupakan memperkirakan kejadian pada masa depan.Peramalan digunakan sebagai alat dalam proses perencanaan yang efesien dan efektif. Proses menerka jumlah kebutuhan di masa depan meliputi kebutuhan dalam kuantitas, kualitas, waktu dan lainnya yang dibutuhkan untuk pemenuhan permintaan barang serta jasa.

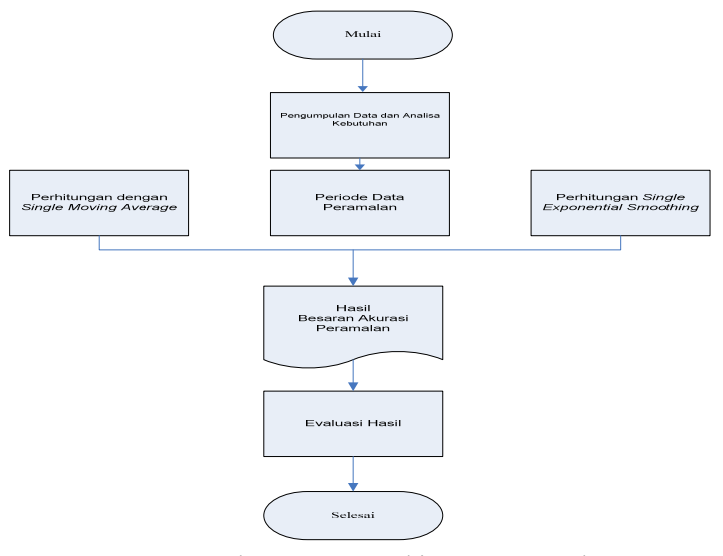

Gambar 1 Proses perhitungan peramalan
Peramalan dibagi menjadi 2 jenis teknik yaitu peramalan konvensional yang berhubungan dengan perhitungan secara matematis dan peramalan menggunakan metode terkait dengan kecerdasan buatan. Banyak terdapat metode konvensional seperti Simple Moving Average dan Exponential Smoothing yang bersifat times series.[8]

\subsection{Simple Moving Average}

Simple Moving Average adalah metode ini tidak menggunakan pembobotannya dalam perhitungan terhadap pergerakan datanya. Metode ini cukup efektif dalam menentukan trend yang sedang terjadi pada suatu objek penelitian. Simple Moving Average merupakan metode prediksi berdasarkan keturutan waktu kuantitatif dalam peramalan. Metode ini menggunakan nilai masa lalu sebagai dasar dalam peramalan pada masa mendatang. Tujuan akhir dari peramalan time series adalah menemukan suatu pola deret waktu dari suatu data dan mengeskploitasinya untuk dijadikan nilai permalan pada masa mendatang [9].

Metode Simple Moving Average dapat dijelaskan seperti berikut:

$$
\mathrm{MA}=\Sigma \mathrm{X} / \text { Jumlah Periode }
$$

Keterangan:

$\mathrm{MA}=$ Moving Average

$\Sigma \mathrm{X}=$ jumlah seluruh data pada tahun kebelakang waktu yang akan dihitung

Jumlah Tahun kebelakang $=$ Jumlah Tahun kebelakang

Rata-rata bergerak dapat ditulis MA $=(n 1+n 2+n 3+\ldots) / n$

Keterangan:

MA = Moving Average

$\mathrm{n} 1=$ data tahun pertama kebelakang

$\mathrm{n} 2=$ data tahun kedua kebelakang

n3 = data tahun ketiga kebelakang ketiga dan seterusnya

$\mathrm{n}=$ Jumlah tahun kebelakang rata-rata bergerak

\subsection{Exponential Smoothing}

Metode Exponential Smoothing adalah pengulangan proses hitung secara terus menerus yang menggunakan data baru. Data akan dibobotkan, dimana pada pembobotan digunakan simbol $\alpha$. Simbol $\alpha$ bisa ditentukan secara bebas, yang mengurangi jumlah error pada peramalan [10]. Nilai konstanta pemulusan, $\alpha$, dapat ditentukan dari nilai 0 dan, karena berlaku: $0<\alpha<1$. Secara metematis, persamaan penulisan eksponential adalah

$\mathrm{St}+1=\alpha \mathrm{Xt}+(1-\alpha) \mathrm{St}$

Dimana: $\mathrm{St}+1=$ Nilai ramalan periode selanjutnya:

$\alpha=$ Konstanta penulisan (0-1).

$\mathrm{Xt}=$ Data pada periode $\mathrm{t}$.

$\mathrm{St}=$ Nilai penulisan data lama atau rata-rata dimuluskan sampai periode $\mathrm{t}-1$.

Nilai $\alpha$ yang menghasilkan tingkat kesalahan yang kecil adalah yang digunakan pada peramalan. Metode ini digunakan untuk meramal sesuatu yang bersifat fluktuasi secara tidak teratur.Permasalahan yang dihadapi saat menggunakan metode ini adalah pemilihan $\alpha$ yang tepat untuk mengurangi error pada peramalan [11]. 
Majalah Ilmiah Teknologi Elektro, Vol. 18, No. 2, Mei - Agustus 2019

DOI: https://doi.org/10.24843/MITE.2019.v18i02.P13

Exponential smoothing merupakan trend pemulusan sederhana dengan dua komponen harus diperbaharui setiap level dan trend. Level merupakan perkiraan yang dimuluskan dari nilai data pada akhir tiap periode. Trend adalah perkiraan yang dihaluskan dari pertumbuhan ratarata pada akhir tiap periode.[12]

Pada setiap periode data juga menampilkan rata-rata error dengan menggunakan metode hitung (Mean Square Error) untuk mencari nilai error terkecil yang di harapkan dalam peramalan.[13]

\section{HASIL DAN EVALUASI}

\subsection{Hasil Moving Average}

Pada perhitungan menggunakan Simple Moving Average di dapatkan perhitungan dengan kurun waktu 7 tahun kebelakang sebelum tahun 2018 antara lain sebagai berikut :

a. Perhitungan ramalan permintaan Ijin Mendirikan Bangunan dengan Metode Simple Moving Average dengan 2 tahun kebelakang dari tahun 2010 hingga 2017 sebesar 891 ijin IMB terbit di akhir 2018 dengan Mean Error sebesar 43, Mean Absolute Deviation sebesar 89, Mean Square Error sebesar 15029, Standar Error sebesar 150 dan Mean Absolute Percent Error yaitu $10 \%$.

TABEL 1

SIMPEL MOVING AVERAGE 2 TAHUN KEBELAKANG

\begin{tabular}{|l|r|r|r|r|r|r|}
\hline \multicolumn{1}{|c|}{ TAHUN IMB } & $\begin{array}{l}\text { JUMLAH } \\
\text { IMB }\end{array}$ & Forecast & Error & IError| & Error"2 & |Pct Error| \\
\hline 2010 & 538 & & & & & \\
\hline 2011 & 776 & & & & & \\
\hline 2012 & 908 & 657 & 251 & 251 & 63001 & $28 \%$ \\
\hline 2013 & 846 & 842 & 4 & 4 & 16 & $0 \%$ \\
\hline 2014 & 953 & 877 & 76 & 76 & 5776 & $8 \%$ \\
\hline 2015 & 966 & 900 & 67 & 67 & 4422 & $7 \%$ \\
\hline 2016 & 952 & 960 & -8 & 8 & 56 & $1 \%$ \\
\hline 2017 & 829 & 959 & -130 & 130 & 16900 & $16 \%$ \\
\hline TOTALS & 6768 & & 260 & 535 & 90172 & $59 \%$ \\
\hline AVERAGE & 846 & & 43 & 89 & 15029 & $10 \%$ \\
\hline Next period forecast & & 891 & $(B i a s)$ & (MAD) & (MSE) & (MAPE) \\
\hline
\end{tabular}

Berikut grafik Simple Moving Average dengan 2 tahun kebelakang :

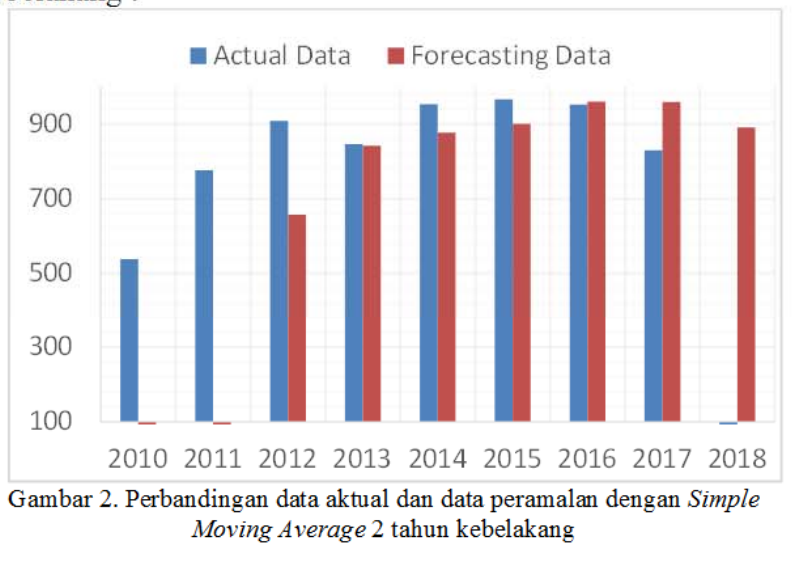

I Gst. Ngr. Agung Yogha P: Peramalan Penerbitan Ijin Mendirik2

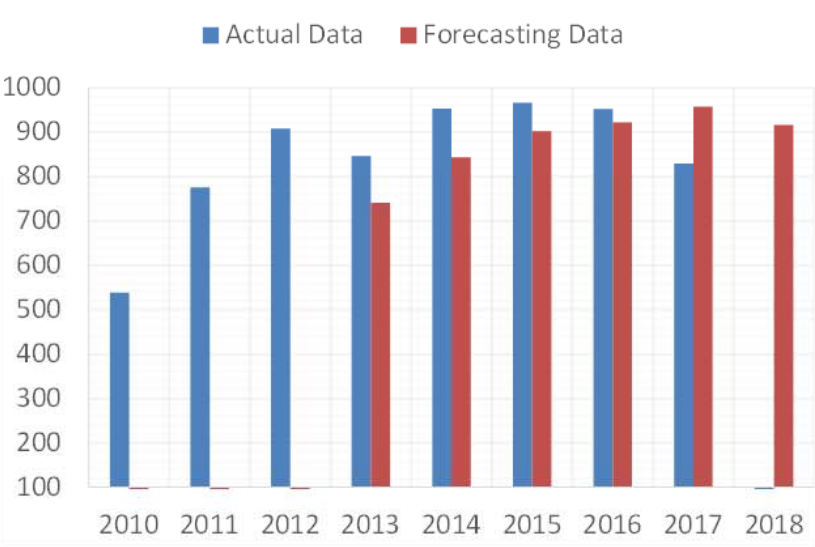

Gambar 3. Perbandingan data aktual dan data peramalan dengan Simple Moving A verage 3 tahun kebelakang

c. Perhitungan ramalan permintaan Ijin Mendirikan Bangunan dengan Metode Simple Moving Average dengan 4 tahun kebelakang dari tahun 2010 hingga 2017 sebesar 925 ijin IMB terbit di akhir 2018 dengan Mean Error sebesar 54, Mean Absolute Deviation sebesar 104, Mean Square Error sebesar 13714, Standar Error sebesar 166 dan Mean Absolute Percent Error yaitu $11 \%$.

TABEL III

SIMPEL MOVING AVERAGE 4 TAHUN KEBELAKANG

\begin{tabular}{|l|r|r|r|r|r|r|}
\hline \multicolumn{1}{|c|}{ TAHUN IMB } & $\begin{array}{l}\text { JUMLAH } \\
\text { IMB }\end{array}$ & Forecast & Error & \multicolumn{1}{l|}{ |Error| } & Error"2 & |Pct Error| \\
\hline 2010 & 538 & & & & & \\
\hline 2011 & 776 & & & & & \\
\hline 2012 & 908 & & & & & \\
\hline 2013 & 846 & & & & & \\
\hline 2014 & 953 & 767 & 186 & 186 & 34596 & $20 \%$ \\
\hline 2015 & 966 & 871 & 95 & 95 & 9073 & $10 \%$ \\
\hline 2016 & 952 & 918 & 34 & 34 & 1139 & $4 \%$ \\
\hline 2017 & 829 & 929 & -100 & 100 & 10050 & $12 \%$ \\
\hline TOTALS & 6768 & & 215 & 415 & 54858 & $45 \%$ \\
\hline AVERAGE & 846 & & 54 & 104 & 13714 & $11 \%$ \\
\hline Next period forecast & & 925 & (Bias) & (MAD) & (MSE) & (MAPE) \\
\hline
\end{tabular}


Berikut grafik Simple Moving Average 4 tahun kebelakang :

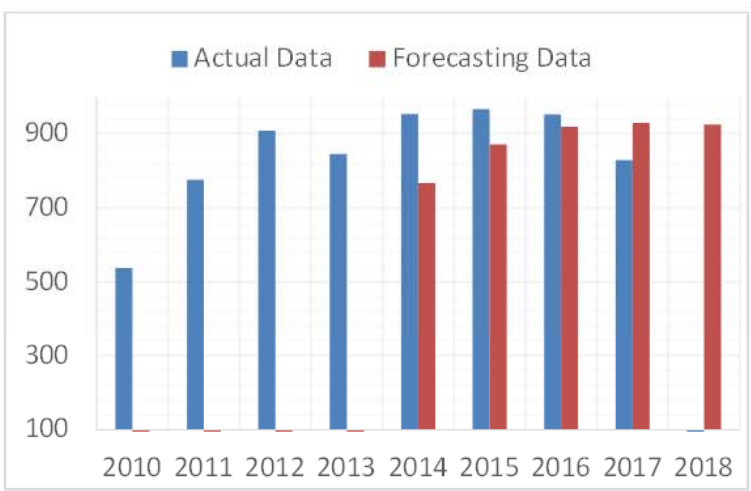

Gambar 4. Perbandingan data aktual dan data peramalan dengan Simple Moving Average 4 tahun kebelakang

d. Perhitungan ramalan permintaan Ijin Mendirikan Bangunan dengan Metode Simple Moving Average dengan 5 tahun kebelakang dari tahun 2010 hingga 2017 sebesar 909 ijin IMB terbit di akhir 2018 dengan tingkat Mean Error sebesar 43, Mean Absolute Deviation sebesar 107, Mean Square Error sebesar 13088, Standar Error sebesar 198 dan Mean Absolute Percent Error mencapai $12 \%$.

TABEL IV

SIMPEL MOVING AVERAGE 5 TAHUN KEBELAKANG

\begin{tabular}{|r|r|r|r|r|r|r|}
\hline \multicolumn{1}{|c|}{ TAHUN IMB } & $\begin{array}{l}\text { JUMLAH } \\
\text { IMB }\end{array}$ & Forecast & Error & \multicolumn{1}{l}{ |Error| } & \multicolumn{1}{l}{ Error"2 } & |Pct Error| \\
\hline 2010 & 538 & & & & & \\
\hline 2011 & 776 & & & & & \\
\hline 2012 & 908 & & & & & \\
\hline 2013 & 846 & & & & & \\
\hline 2014 & 953 & & & & & \\
\hline 2015 & 966 & 804 & 162 & 162 & 26179 & $17 \%$ \\
\hline 2016 & 952 & 890 & 62 & 62 & 3869 & $7 \%$ \\
\hline 2017 & 829 & 925 & -96 & 96 & 9216 & $12 \%$ \\
\hline 2018 & 0 & 909 & -909 & 909 & 826645 & $0 \%$ \\
\hline TOTALS & 6768 & & -781 & 1229 & 865909 & $35 \%$ \\
\hline AVERAGE & 752 & & -195 & 307 & 216477 & $9 \%$ \\
\hline Next period forecast & & 740 & (Bias) & (MAD) & (MSE) & (MAPE) \\
\hline & & & & Std err & 658 & \\
\hline
\end{tabular}

Berikut grafik Simple Moving Average 5 tahun kebelakang :

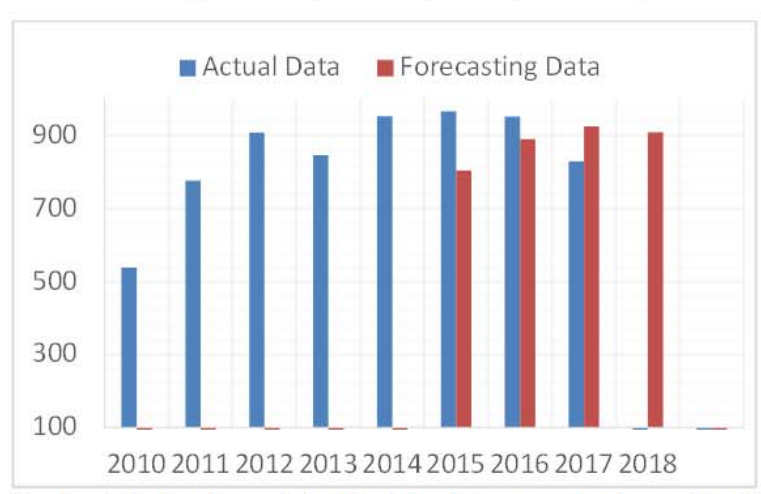

Gambar 5. Perbandingan data aktual dan data peramalan dengan Simple Moving Average 5 tahun kebelakang

e. Perhitungan ramalan permintaan Ijin Mendirikan Bangunan dengan Metode Simple Moving Average dengan 6 tahun kebelakang dari tahun 2010 hingga 2017 sebesar 909 ijin IMB terbit di akhir 2018 dengan tingkat Mean Error sebesar 25, Mean Absolute Deviation sebesar 96, Mean Square Error sebesar 9833 dan Mean Absolute Percent Error mencapai $11 \%$. Standar Error sebesar NA di karenakan pada saat perhitungan nilai total dari MSE yaitu 9833 dicarikan akar pangkat dari 9833 tersebut kemudian dibagi dengan seluruh jumlah nilai yang terdapat pada MSE yaitu 6 tahun kebelakang kemudian di kurangi 2.

TABEL V.

SIMPEL MOVING AVERAGE 6 TAHUN KEBELAKANG

\begin{tabular}{|l|r|r|r|r|r|r|}
\hline \multicolumn{1}{|c|}{ TAHUN IMB } & $\begin{array}{l}\text { JUMLAH } \\
\text { IMB }\end{array}$ & Forecast & Error & |Error| & Error'2 & |Pct Error| \\
\hline 2010 & 538 & & & & & \\
\hline 2011 & 776 & & & & & \\
\hline 2012 & 908 & & & & & \\
\hline 2013 & 846 & & & & & \\
\hline 2014 & 953 & & & & & \\
\hline 2015 & 966 & & & & & \\
\hline 2016 & 952 & 831 & 121 & 121 & 14601 & $13 \%$ \\
\hline 2017 & 829 & 900 & -71 & 71 & 5065 & $9 \%$ \\
\hline 2018 & 0 & 909 & -909 & 909 & 826281 & $0 \%$ \\
\hline TOTALS & 6768 & & -859 & 1101 & 845946 & $21 \%$ \\
\hline AVERAGE & 752 & & -286 & 367 & 281982 & $7 \%$ \\
\hline Next period forecast & & 758 & (Bias) & (MAD) & (MSE) & (MAPE) \\
\hline & & & & Std err & 920 & \\
\hline
\end{tabular}

Berikut grafik Simple Moving Average 6 tahun kebelakang : 


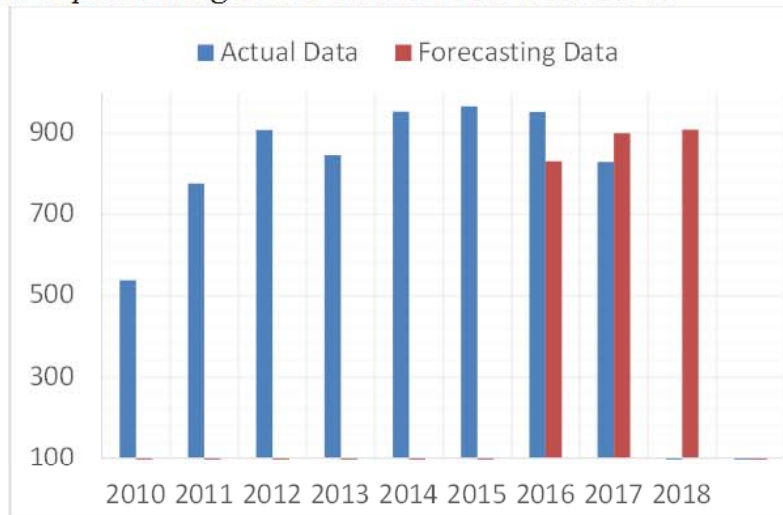

Gambar 6. Perbandingan data aktual dan data peramalan dengan Simple Moving Average 6 tahun kebelakang

f. Perhitungan ramalan permintaan Ijin Mendirikan Bangunan dengan Metode Simple Moving Average dengan 7 tahun kebelakang dari tahun 2010 hingga 2017 sebesar 890 ijin IMB terbit di akhir 2018 dengan dengan tingkat Mean Error sebesar -19, Mean Absolute Deviation sebesar 19, Mean Square Error sebesar 377 dan Mean Absolute Percent Error mencapai $2 \%$. Standar Error sebesar NA di karenakan pada saat perhitungan nilai total dari MSE yaitu 377 dicarikan akar pangkat dari 377 tersebut kemudian dibagi dengan seluruh jumlah nilai yang terdapat pada MSE yaitu 7 tahun kebelakang kemudian di kurangi 2.

TABEL VI

Simpel MOVING AVERAGE 7 TAHUN KEBELAKANG

\begin{tabular}{|l|r|l|l|l|l|l|}
\hline \multicolumn{1}{|c|}{ TAHUN IMB } & \multicolumn{1}{l}{ JUMLAH } & Forecast & Error & |Error| & Error'2 & |Pct Error| \\
\hline 2010 & 538 & & & & & \\
\hline 2011 & 776 & & & & & \\
\hline 2012 & 908 & & & & & \\
\hline 2013 & 846 & & & & & \\
\hline 2014 & 953 & & & & & \\
\hline 2015 & 966 & & & & & \\
\hline 2016 & 952 & & & & & \\
\hline 2017 & 829 & 848 & -19 & 19 & 377 & $2 \%$ \\
\hline TOTALS & 6768 & & -19 & 19 & 377 & $2 \%$ \\
\hline AVERAGE & 846 & & -19 & 19 & 377 & $2 \%$ \\
\hline Next period forecast & & 890 & (Bias) & (MAD) & (MSE) & (MAPE) \\
\hline & & & & Std err & NA & \\
\hline
\end{tabular}

Berikut grafik Simple Moving Average 7 tahun kebelakang :

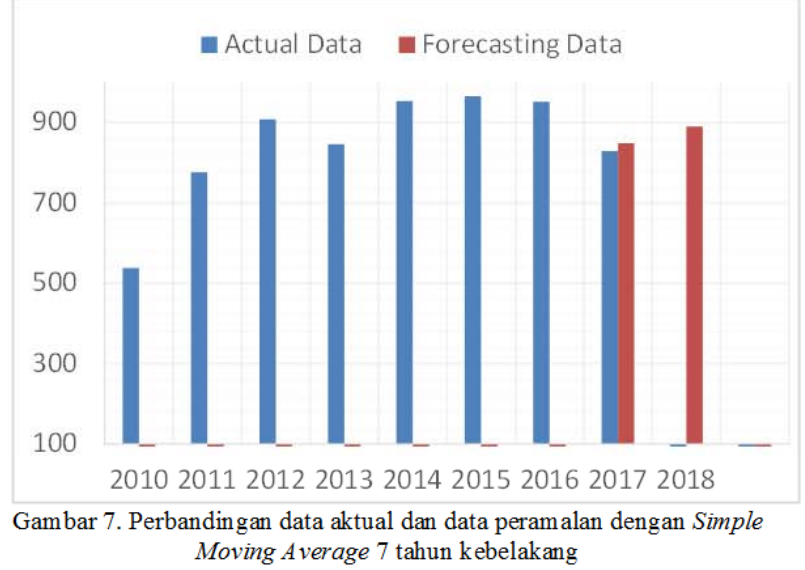

Peramalan yang dilakukan dengan Simple Moving Average di dapatkan menggunakan data uji dengan 3 tahun kebelakang memiliki nilai error terkecil mencapai $10 \%$ di karenakan memiliki nilai paling dekat dengan data aktual saat ini ( tahun 2018 ) pada proses peramalannya. Data 3 kebelakang memiliki nilai paling stabil diantara nilai dengan pengujian 2 tahun dan setelah 3 tahun kebelakang yang masih memiliki nilai error mencapai $11 \%$ hanya saja sangat jauh dari data aktual yang di harapkan. Pada saat menggunakan data 5, 6 dan 7 tahun kebelakang data yang di dapat memang memiliki error yang lebih kecil dari $9 \%$ tetapi data peramalan yang akan muncul pada tahun 2018 sangat kecil yang jauh dari data actual.

\subsection{Hasil Exponential Smoothing}

Pada perhitungan menggunakan Exponential Smoothing dengan perhitungan dari $\alpha=0,10, \alpha=0,50, \alpha=0,70$ dan $\alpha=$ 0,90 maka didapatkan hasil perhitungan sebagai berikut :

a. Perhitungan peramalana Ijin Mendirikan Bangunan (IMB) dengan metode Exponential Smoothing $\alpha=$ 0,10 dengan 2 periode analisis dari tahun 2010 hingga tahun 2017 sebesar 724 ijin IMB terbit di akhir 2018 dengan Mean Absolute Deviation (MAD) sebesar 266, Mean Squared Error sebesar 75758, Standar Error sebesar 326 dan Mean Absolute Percent Error sebesar $30 \%$.

TABEL VII

\begin{tabular}{|c|c|c|c|c|c|c|}
\hline \multirow[b]{2}{*}{ TAHUN IMB } & \multicolumn{5}{|c|}{ EXPONENTIAL SMOOTHING A $=0,10$} & \multirow[b]{2}{*}{ |Pct Error| } \\
\hline & $\begin{array}{l}\text { JUMLAH } \\
\text { IMB }\end{array}$ & Forecast & Error & |Error| & Error»2 & \\
\hline 2010 & 538 & & & & & \\
\hline 2011 & 776 & 538 & 238 & 238 & 56644 & $31 \%$ \\
\hline 2012 & 908 & 562 & 346 & 346 & 119854 & $38 \%$ \\
\hline 2013 & 846 & 596 & 250 & 250 & 62290 & $30 \%$ \\
\hline 2014 & 953 & 621 & 332 & 332 & 109973 & $35 \%$ \\
\hline 2015 & 966 & 655 & 311 & 311 & 97007 & $32 \%$ \\
\hline 2016 & 952 & 686 & 266 & 266 & 70923 & $28 \%$ \\
\hline 2017 & 829 & 712 & 117 & 117 & 13615 & $14 \%$ \\
\hline TOTALS & 6768 & & 1860 & 1860 & 530307 & $207 \%$ \\
\hline AVERAGE & 846 & & 266 & 266 & 75758 & $30 \%$ \\
\hline \multirow{2}{*}{ Next period forecast } & & 724 & (Bias) & (MAD) & (MSE) & (MAPE) \\
\hline & & & & Std err & 326 & \\
\hline
\end{tabular}

Berikut grafik Exponential Smoothing $\alpha=0,10$ p-ISSN:1693-2951; e-ISSN: 2503-2372 


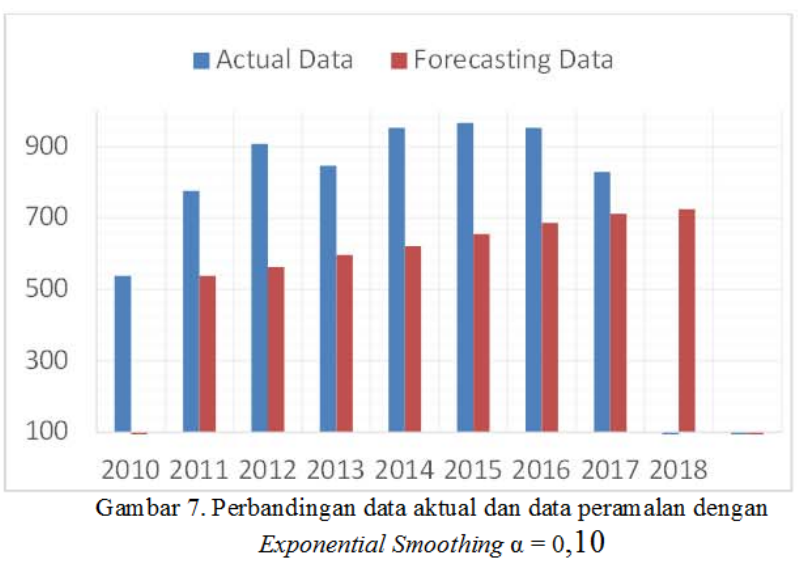

b. Perhitungan peramalana Ijin Mendirikan Bangunan (IMB) dengan metode Exponential Smoothing $\alpha=$ 0,50 dengan 2 periode analisis dari tahun 2010 hingga tahun 2017 sebesar 884 ijin IMB terbit di akhir 2018 dengan tingkat Mean Error sebesar 99, Mean Absolute Deviation sebesar 130, Mean Square Error sebesar 23203, Standar Error sebesar 180 dan Mean Absolute Percent Error mencapai $15 \%$.

TABEL VIII

EXPONENTIAL SMOOTHING A $=0,50$

\begin{tabular}{|l|r|r|r|r|r|r|}
\hline \multicolumn{1}{|c|}{ TAHUN IMB } & $\begin{array}{l}\text { JUMLAH } \\
\text { IMB }\end{array}$ & Forecast & Error & |Errorl & Error'2 & | Pct Errorl \\
\hline 2010 & 538 & & & & & \\
\hline 2011 & 776 & 538 & 238 & 238 & 56644 & $31 \%$ \\
\hline 2012 & 908 & 657 & 251 & 251 & 63001 & $28 \%$ \\
\hline 2013 & 846 & 783 & 64 & 64 & 4032 & $8 \%$ \\
\hline 2014 & 953 & 814 & 139 & 139 & 19252 & $15 \%$ \\
\hline 2015 & 966 & 884 & 82 & 82 & 6786 & $9 \%$ \\
\hline 2016 & 952 & 925 & 27 & 27 & 739 & $3 \%$ \\
\hline 2017 & 829 & 938 & -109 & 109 & 11970 & $13 \%$ \\
\hline TOTALS & 6768 & & 691 & 910 & 162423 & $105 \%$ \\
\hline AVERAGE & 846 & & 99 & 130 & 23203 & $15 \%$ \\
\hline Next period forecast & & 884 & (Bias) & (MAD) & (MSE) & (MAPE) \\
\hline & & & & Std err & 180 & \\
\hline
\end{tabular}

Berikut grafik Exponential Smoothing $\alpha=0,50$

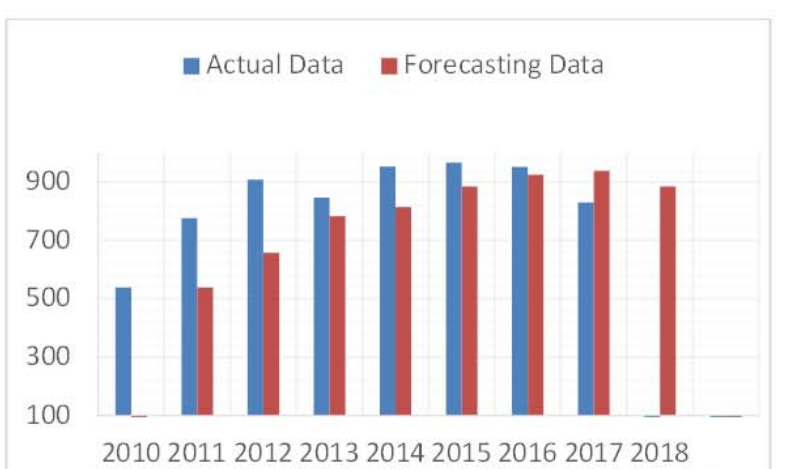

Gambar 8. Perbandingan data aktual dan data peramalan dengan Exponential Smoothing $\alpha=0,50$

c. Perhitungan peramalana Ijin Mendirikan Bangunan (IMB) dengan metode Exponential Smoothing $\alpha=$ 0,70 dengan 2 periode analisis dari tahun 2010 hingga tahun 2017 sebesar 866 ijin IMB terbit di akhir 2018 dengan Mean Error sebesar 67, Mean Absolute Deviation sebesar 103, Mean Square Error sebesar 18085, Standar Error sebesar 159 dan Mean Absolute Percent Error mencapai $12 \%$.

TABE IX

EXPONENTIAL SMOOTHING A $=0,70$

\begin{tabular}{|c|c|c|c|c|c|c|}
\hline TAHUN IMB & $\begin{array}{l}\text { JUMLAH } \\
\text { IMB }\end{array}$ & Forecast & Error & |Error| & Error"2 & |Pct Error| \\
\hline 2010 & 538 & & & & & \\
\hline 2011 & 776 & 538 & 238 & 238 & 56644 & $31 \%$ \\
\hline 2012 & 908 & 705 & 203 & 203 & 41372 & $22 \%$ \\
\hline 2013 & 846 & 847 & -1 & 1 & 1 & $0 \%$ \\
\hline 2014 & 953 & 846 & 107 & 107 & 11386 & $11 \%$ \\
\hline 2015 & 966 & 921 & 45 & 45 & 2026 & $5 \%$ \\
\hline 2016 & 952 & 952 & 0 & 0 & 0 & $0 \%$ \\
\hline 2017 & 829 & 952 & -123 & 123 & 15166 & $15 \%$ \\
\hline TOTALS & 6768 & & 468 & 718 & 126595 & $84 \%$ \\
\hline AVERAGE & 846 & & 67 & 103 & 18085 & $12 \%$ \\
\hline \multirow[t]{2}{*}{ Next period forecast } & & 866 & (Bias) & (MAD) & (MSE) & (MAPE) \\
\hline & & & & Std err & 159 & \\
\hline
\end{tabular}

Berikut grafik Exponential Smoothing $\alpha=0,70$

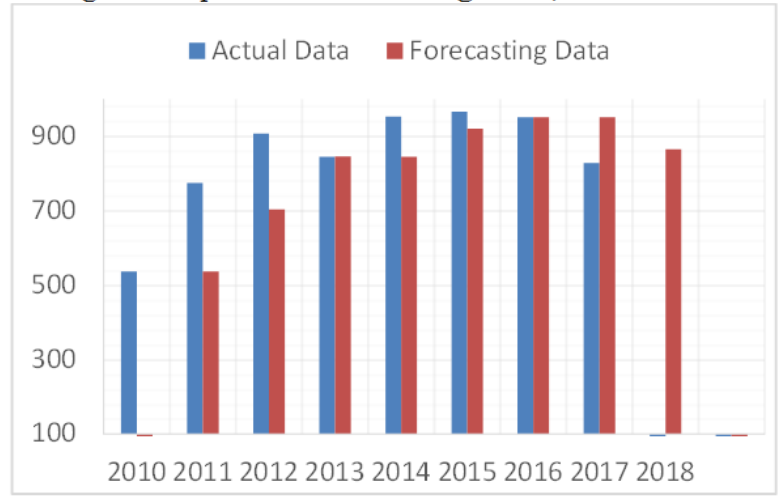

Gambar 8. Perbandingan data aktual dan data peramalan dengan Exponential Smoothing $\alpha=0,70$

d. Perhitungan peramalana Ijin Mendirikan Bangunan (IMB) dengan metode Exponential Smoothing $\alpha=$ 
Majalah Ilmiah Teknologi Elektro, Vol. 18, No. 2, Mei - Agustus 2019

DOI: https://doi.org/10.24843/MITE.2019.v18i02.P13

0,90 dengan 2 periode analisis dari tahun 2010 hingga tahun 2017 sebesar 841 ijin IMB terbit di akhir 2018 dengan Mean Error sebesar 48, Mean Absolute Deviation sebesar 100, Mean Square Error sebesar 15663, Standar Error sebesar 148 dan Mean Absolute Percent Error mencapai $12 \%$.

TABEL X

. EXPONENTIAL SMOOTHING A $=0,90$

\begin{tabular}{|c|c|c|c|c|c|c|}
\hline TAHUN IMB & $\begin{array}{l}\text { JUMLAH } \\
\text { IMB }\end{array}$ & Forecast & Error & |Error| & Error"2 & |Pct Error| \\
\hline 2010 & 538 & & & & & \\
\hline 2011 & 776 & 538 & 238 & 238 & 56644 & $31 \%$ \\
\hline 2012 & 908 & 752 & 156 & 156 & 24274 & $17 \%$ \\
\hline 2013 & 846 & 892 & -46 & 46 & 2155 & $5 \%$ \\
\hline 2014 & 953 & 851 & 102 & 102 & 10477 & $11 \%$ \\
\hline 2015 & 966 & 943 & 23 & 23 & 540 & $2 \%$ \\
\hline 2016 & 952 & 964 & -12 & 12 & 136 & $1 \%$ \\
\hline 2017 & 829 & 953 & -124 & 124 & 15418 & $15 \%$ \\
\hline TOTALS & 6768 & & 337 & 702 & 109644 & $83 \%$ \\
\hline AVERAGE & 846 & & 48 & 100 & 15663 & $12 \%$ \\
\hline \multirow[t]{2}{*}{ Next period forecast } & & 841 & (Bias) & (MAD) & (MSE) & (MAPE) \\
\hline & & & & Std err & 148 & \\
\hline
\end{tabular}

Berikut grafik Exponential Smoothing $\alpha=0,90$

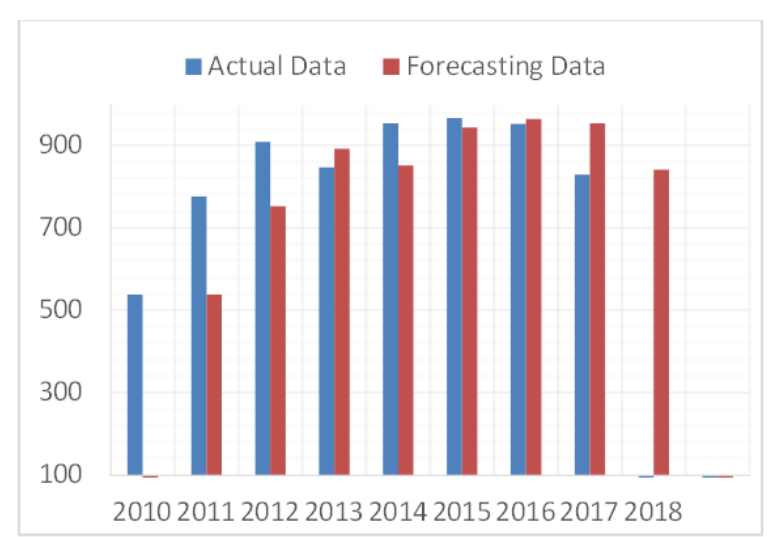

Gambar 8. Perbandingan data aktual dan data peramalan dengan Exponential Smoothing $\alpha=0,90$

Pada hasil didapatkan bahwa $\alpha=0,70$ dan $\alpha=0,90$ memiliki tingkat error yang paling kecil sama pula hingga mencapai $12 \%$. Alasannya karena pada hakikatnya terdapat alpha yang memiliki nilai dari $\alpha=0,01$ hingga alpha bernilai $\alpha=0,99$ sehingga dalam perjalanan hitungnya data hitung akan melewati rentan uji data dari 0,01 sampai 0,70 sebanyak 69 kali hitungan pada alpha 0,70 . Sedangkan pada $\alpha=0,90$ melewati proses hitung mencapai proses hitung sebanyak 89 kali proses. Sehingga mendapatkan hasil error yang paling sedikit diantara $\alpha=0,10$ dan $\alpha=0,50$ yang hanya melewati masa rentan uji data hanya sebanyak 9 kali dan 49 kali pada masing-masing tahapannya.

\section{KESIMPULAN}

Berdasarkan penelitian, perancangan sistem, implementasi dan pengujian hasil penelitian yang telah dilaksanakan maka dapat didapatkan sebuah kesimpulan sebagai berikut ini : a. Pada hasil peramalan untuk jumlah ijin terbit tahun 2018 dengan metode Simple Moving Average dengan 3 periode memaparkan tingkat error terkecil yaitu $10 \%$ berserta jumlah ijin yang terbit sebesar 916 pada tahun 2018.

b. Pada hasil peramalan jumlah ijin yang terbit pada tahun 2018 dengan Exponential Smoothing diketahui bahwa $\alpha=0,70$ dan $\alpha=0,90$ memiliki tingkat error di bawah $12 \%$ dengan iterasi sebanyak 69 dan 89 kali pada setiap alpha.

\section{REFERENS}

[1] Peraturan Daerah Kabupaten Gianyar Nomor 8 Tahun 2013 Tentang Bangunan Gedung.

[2] Jefrisen, Studi Tentang Pelayanan Pemberian Izin Mendirikan Bangunan Di Kantor Pelayanan Perizinan Terpadu (KP2TSP) Kabupaten Kutai Barat,2016

[3] Nurul Agus Irawan, Implementasi Aturan Ijin Mendirikan Bangunan (IMB) Di Kawasan Sekitar Bencana Lumpur Sidoarjo, 20dkk16

[4] Pada Peraturan Menteri Pekerjaan Umum Dan Perumahan Rakyat No.05/PRT/M/2016

[5] Tyas Wedhasari, Analisa Penggunaan Metode Peramalan Pada Perusahaan Retail Sistem Tradisional Market, 2015

[6] Hari Utari, dkk , Perancangan Aplikasi Peramalan Permintaan Kebutuhan Tenaga Kerja Pada Perusahaan Outsourcing Menggunakan Algoritma Simple Moving Average, 2016

[7] Kristien Margi S, Sofian Pendawa W, Analisa Dan Penerapan Metode Exponential Smoothing Untuk Prediksi Penjualan Pada Periode Tertentu, 2015

[8] I Gusti Ngurah Rai Dharma Widura, dkk, Penentuan Target Pajak Kendaraaan Bermotor Di Provinsi Bali Menggunakan ARIMA dan Algoritma Genetik, 2018

[9] Novian Anggis Suwastika, dkk, Model Prediksi Simple Moving Average Pada Auto-Scaling Cloud Computing, 2015

[10] Riza Rahmadayanti, dkk, Perbandingan Keakuratan Metode Autoregressive Integrated Moving Average ( ARIMA ) dan Exponential Smoothing Pada Peramalan Penjualan Semen Di PT. Sinar Abadi, 2015

[11] David Widodo,Seng Hansun, Implementasi Simple Moving Average dan Exponential Moving Average dalam Menentukan Tren Harga Saham Perusahaan, 2015

[12] I Nyoman Sumerta Yasa, dkk, Peramalan Kurs Rupiah Terhadap US Dollar Menggunakan Metode Hbrid, 2017

[13] I Putu Susila Handika, dkk, Perbandingan Metode Extreme Learning Machine dan Particle Swam OptimizationExtreme Learnig Machine untuk Peramalan Jumlah Penjualan Barang, 2016

I Gst. Ngr. Agung Yogha P: Peramalan Penerbitan Ijin Mendirikan... 
\{ Halaman ini sengaja dikosongkan \} 